\title{
A Critique of Descartes' Mind-Body Dualism
}

\section{Akomolafe Akinola Mohammed}

\begin{abstract}
In this enterprise, I shall present Descartes' theory of 'methodic doubt,' moving systematically as he (Descartes) himself would suppose we do, from the establishment of the being of his thinking self (his soul), through the existence of a non-mischievous, infinitely, perfect Being, God, to the existence of a corporeal, extended substance (his body), as distinct from his mind; and the ultimate interaction of the two distinct and separate substances: mind and body. Also, I shall give a critical evaluation of Descartes' method, bringing into focus the alternative theories of other philosophers aimed at resolving the Cartesian dualism. The scientific standpoint on the issue shall also be considered. Through these analyses, I shall establish the thesis that, the interaction of mind and body is only probable.
\end{abstract}

Keywords: Descartes, Cartesian method, mind-body dualism, cogito

\section{Introduction}

$\mathrm{D}$ escartes, who was born in 1596 in France, had profited largely by the great scientific and philosophical illumination of his epoch. He owed much to the Renaissance both in France and in England. He was a mathematician, scientist and philosopher. He sought to lay a new foundation for philosophy with the mathematical method. How different, as revealed in his letters and other writings, is Descartes' method? As a thinker, he was of the intuitive type, foreseeing his conclusions ahead of the steps required in establishing them. This goes far to explain why he showed himself to be so strangely unable to learn from those who differed from him in any fundamental regard, as, for example, from Hobbes or Gassendi.

The attitude of Descartes towards the philosophers who preceded him is remarkable - he deliberately ignored them. Although well-acquainted with their works, he built his own system as if he knew nothing of them. Not that he personally held either ancient or modern philosophers in contempt. He was not presumptuous 
as to believe that his mind was superior to theirs. He even acknowledged that many truths had been discovered before he created his method, but he did not wish to accept these truths on tradition. He was determined to discover them for himself. By means of his method, he proposed to obtain these truths, no longer mixed pellmell with a mass of doubtful or erroneous opinions, but set in their right places, and accompanied with their proofs.

Thus, Descartes sought not what is probable, but what is true. The first requisite in finding what is true he took to be the casting aside of the philosophy taught in his time, which contented itself with probability and gave no satisfactory demonstrations. Therefore, though he occasionally retained the vocabulary of scholasticism, he even borrowed some of his matter from it (for instance, in the ontological argument for the existence of God), nevertheless, he broke distinctly and completely from the method and spirit of the philosophy of his age. Thus was formed in his mind, the method which was destined in his plan to replace the 'useless' and 'sterile' ancient logic: He vowed never to accept a thing as true which he did not clearly know to be such.

\section{Descartes' Method}

Having thus been fascinated by the mathematical method of clarity, certainly and indubitability, Descartes considers philosophy as an antithesis of those mathematical virtues; for he sees philosophy as being founded on doubtful and shaky grounds. Determined therefore to give philosophy a firm foundation with the mathematical method as its base, he resolves to search and discover one thing which is certain and indubitable. Such a certainty, if found, would be the foundation of the philosophical system upon which all other truths would be built. He thus sets on this arduous task, by systematically questioning and doubting all that he used to know. ${ }^{1}$

In his view, there is the need for him to sweep away all the opinions he hitherto holds, so that they may later on be replaced either by others which are better, or by the same views, more genuinely held, after they might have been rationally confirmed. He thus resolves to apply himself earnestly to the general overthrow of all his former opinions, so that it would not be necessary for him to show that the whole of these are false. For him, it would be sufficient to justify the rejection of the whole if he should find in each some ground for doubt. ${ }^{2}$

Having thus doubted and rejected everything in the world as true, Descartes then wants to see if he can come to any truth which he will find impossible to doubt. He

\footnotetext{
${ }^{1}$ G. N.A. Vesey ed., Body and Mind, (London: George Allen \& Unwin Ltd., 1964), 22.

2 R. Descartes, The Meditations, Trans by John Veitch, (Illinios: The Open Court Publishing Company, 1966), 22.
} 
is reluctant to find one so easily, for he has doubted virtually everything, including his own very existence. ${ }^{3}$

Here, Descartes' denial of his own existence: his body, hands, eyes, legs, etc, is extenuated by dreaming situation. According to him, how could he be sure that he was not presently dreaming, since whenever he was in dream, he seemed to have things which in reality, he did not have. He thus doubts virtually everything, even including mathematical propositions like $2+2=4$.

\section{Cogito Ergo Sum}

In the process of doubting everything, however, Descartes realises one fact; and that is that, he, Descartes, the doubting Thomas, cannot doubt the fact that he is thinking, for by doubting that he is thinking, he is actually confirming it; for thinking presupposes doubting. In as much as thinking itself implies existence; that is, one has to exist before he can think; it follows necessarily that Descartes can derive the fact of his existence from his thinking essence. This way, he discovers his indubitable truth or first principle: 'Cogito Ergo Sum,' meaning, 'I think, therefore, I exist.'

According to Descartes, this maxim is an indubitable truth, it cannot be doubted, for any attempt to doubt that, 'I think, therefore I exist,' is a confirmation of the fact of my existence, because doubting itself involves thinking, and one has to exist in order to think. Even if one is dreaming or is being deceived by an evil genius, it is a further proof that one exists, since one must exist before he can dream or be deceived. ${ }^{4}$

So far, 'Cogito ergo sum' has only succeeded in establishing that Descartes is a thinking being (mind or soul) no more, no less. On this, let Descartes speak for himself:

I do not now admit anything which is not necessarily true: to speak accurately I am not more than a thing which thinks that is to say a mind or a soul or an understanding, or a reason which are terms whose significance was formerly unknown to me. I am, however, a real thing and really exist; but what thing? I have answered: a thing which thinks. ${ }^{5}$

Thus for now, the only truth Descartes knows for certain, is that he is a thinking being, who exists as a thinking being. That he has a body is yet to be proved beyond all doubts. He is not yet sure whether or not anything else exists in the world

\footnotetext{
${ }^{3}$ Ibid., 23

${ }^{4} \mathrm{Ibid}$.

${ }^{5}$ Vesey, Body and Mind, 24.
}

(C) 2012 Akomolafe Akinola Mohammed http://www.kritike.org/journal/issue_11/mohammed june2012.pdf ISSN 1908-7330 
apart from him as a thinking being. This also needs some proving. Could it be that all other things in the world are not different from him with his thinking characteristic? This has to be proved as well.

It must be noted, however, that Descartes embarks on his 'methodic doubt,' not for the purpose of doubting for doubting sake, but for the aim of arriving at conclusions which can enable him tackle other problems that bother on uncertainties.

In his letter to Reneri for Pollot in April 1638, Descartes asserts:

Although the Pyrrhonians reached no certain conclusion from their doubts, it does not follow that no one can. I would try now to show how they can be used to prove God's existence and to clear up the difficulties which remain in what I wrote. $^{6}$

Clear and distinct ideas are necessarily true. Having established his existence, Descartes now wishes to investigate this basic truth with a view to knowing what makes it indubitable. He eventually comes to the conclusion that what makes a true proposition indubitable is the fact that if the truth affirmed by the proposition is perceived clearly and distinctly, then the proposition must be true.

God's existence. To be sure that God is not deceiving him into believing that what he perceives clearly and distinctly is true, he then moves to prove the existence of a God that is not disposed towards deceiving him. According to him, a finite being like him could not possibly have an infinite idea of God's existence if, in reality, God does not exist. ${ }^{7}$ Thus, Descartes ends up affirming God's existence: "And thus it is absolutely necessary to conclude, from all that I have before said that God exists." ${ }^{8}$ Hence Descartes ends up affirming God's existence.

Can God be a deceiver? Having now been sure of God's existence, Descartes wants to know if God can be a deceiver. On this matter, he reverts to his idea of God as an infinitely perfect Being, who has no defect (of imperfection or not existing) in His essence.

From Descartes' letter to Rev. Father Mersenne in April 1641, he has this to say concerning the non-deceitful nature of God:

Those who say that God continually deceives the damned, and that he might similarly be continually deceiving us, contradict the foundation of faith and all our belief, which is

${ }^{6}$ K. Anthony ed., Descartes' Philosophical Letters (London: Oxford University Press, 1970),

52.

${ }^{7}$ Descartes, The Meditations, 61-62.

${ }^{8}$ Ibid., 54.

(C) 2012 Akomolafe Akinola Mohammed http://www.kritike.org/journal/issue_11/mohammed june2012.pdf ISSN 1908-7330 
that God cannot lie. This is stated over and over again in so many places in St. Augustine, St. Thomas and others that I am surprised that any theologian denies it. They will have to abandon all certainty if they do not admit as an axiom that God cannot deceive us. ${ }^{9}$

At this juncture, Descartes is only sure of the following: that he has mind; that whatever proposition he perceives clearly and distinctly to be true, must be true; that God exists; and that God cannot deceive him. His next task is to prove whether he has body or not. For now, he is not sure whether he has body or not. To be sure of this, he first doubts the reliability of his senses, arguing that often times, his senses present him with experiences in dreams, which never materialise in his waking life. On this he writes:

But if it is so that I have no body it is also true that I can neither walk nor take nourishment. Another attribute is sensation. But one cannot feel without body, and besides I have thought I perceived many things during sleep that I recognized in my waking moments as not having been experienced at all. ${ }^{10}$

Descartes sets out to show that he has body by wondering what more he is apart from his thinking self (mind). Could it be that he is dependent for his existence on what, though not known to him, is not different from himself? Nor could this knowledge of the self have been acquired through what the imagination might presume to 'feign. ${ }^{11}$

At this point, according to Descartes, apart from him existing as a thinking being, that is, as a mind or soul, he perceives clearly and distinctly that he performs some physical activities through some bodily organs such as head, hands, feet and other parts of him, which implies that he has a body, an extended substance, which is distinct from his essence as a thinking being. ${ }^{12}$

\section{The Dualism and Interaction between the Mind and Body}

The inescapable conclusion Descartes thus comes to is that he possesses mind, his thinking being, as distinct from his body, extended essence. This means that there are two aspects of man, corresponding to two substances: spiritual

\footnotetext{
${ }^{9}$ Anthony, Descartes' Philosophical Letters, 99.

${ }^{10}$ Vesey, Body and Mind , 24.

${ }^{11}$ Ibid., 25.

${ }^{12}$ Ibid.
}

(C) 2012 Akomolafe Akinola Mohammed http://www.kritike.org/journal/issue 11/mohammed june2012.pdf ISSN 1908-7330 
substance, (mind), which has thinking as its essence and material substance (body), with extension as its essence. Mind and body are therefore, two kinds of substance, each of which is distinctly different, and can exist independent of each other.

With Descartes' establishment of his soul or mind as existing independent and distinct from his body, the seed of Cartesian dualism was thus sowed.

The thrust of the matter now is, and here lies the Cartesian mind-body quandary. Having established the existence of the mind as distinct from the body, Descartes is now faced with the question as to whether there is any interaction between them (mind and body)? He admits that although, mind and body are two different and distinct substances, but they nevertheless interact. According to him, when for instance, I am hurt, I feel pain. As a result, the mind reacts to what happens to the body. The fact that what happens to the body also affects the mind and viceversa shows that there must be a close affinity and interaction between the two (Descartes, 1966:94). ${ }^{13}$ In Descartes' Letter to Regius in January 1642, he asserts that there is an interaction between the mind and the body. For him, not only does the body influence the mind, the mind too influences and moves the body to action; but the mind is superior to the body in this interaction. ${ }^{14}$

The pertinent question at this juncture is: How does this mind-body or body-mind interaction take place? How can a spiritual substance interact with a material substance, and vice-versa? Put differently, since all of the forms that bodies occur in involve only various extensional features, never mental ones; similarly, no form of thought involves extension. That means the realms of thought and extension is completely different. How then can mental events have anything to do with physical ones and vice-versa, since the one occurs in space and the other is nonextended thought with no physical properties whatsoever?

Descartes' answer is that the interaction takes place at the 'pineal gland' which is situated in the inner-most part of the brain. It is here, according to him, that the mind comes into contact with the body through the animal spirits. ${ }^{15}$

Still explaining how mind and body act on each other, Descartes was quoted as writing that:

The machine of the body is so formed that from the simple fact that this gland is diversely moved by the soul, or by such other cause, whatever it is, it thrusts the spirits which surround it towards the pores of the brain, which conduct them by the nerves into the muscles by which means it causes them to move the limbs. ${ }^{16}$

\footnotetext{
${ }^{13}$ Descartes, The Meditations, 94.

${ }^{14}$ Anthony, Descartes' Philosophical Letters, 153.

${ }^{15}$ Ibid., 192.

${ }^{16}$ Vesey, Mind and Body, 48
}

(C) 2012 Akomolafe Akinola Mohammed http://www.kritike.org/journal/issue 11/mohammed june2012.pdf ISSN 1908-7330 
Descartes believes that animal behaviour: in the pursuit of food, in the tending of offspring, and in guarding against enemies; exhibits features which in man would be called signs of memory and free initiative. He has to discover in the animal organism mechanism sufficient to explain all these varied adaptations. This he believes himself to have done in the account which he gives to the sensus communis, located in the pineal gland. Noting that with the two eyes, we apprehend one single thing; with the two ears, one single sound; and with the two hands, when they are employed in touching one and the same object, again a single body, Descartes argues that there must be a centre in which the incoming stimuli are combined and co-ordinated. He locates this in the upper brain, where there is only one organ (a small gland, about the size of a pea, commonly entitled the 'pineal gland'), which is single and also central in position. He insists that this gland is as truly corporeal as the eye or the hand, and he entitles it sometimes the phantasia vel imaginatio, and sometimes the sensus communis.

This phantasy has to be conceived as a genuine part of the body, of sufficient magnitude to allow of its different parts assuming diverse shapes in distinctnesss from each other, and to enable those parts to acquire the habit of retaining those shapes for some time - this being what we entitle the memory.

In this connection, Descartes is careful to explain that the senses do not exist in bodies otherwise than as modifications of the spatial mechanical qualities. Only so, he holds, could we understand the mechanistic manner in which the senseorgans and the pineal gland react to external stimuli. ${ }^{17}$

Through the functions of the pineal gland, Descartes proceeds to account for our sense - experiences of the outer world. The objects touched, the field seen, imprint patterns of themselves on the surface of the touching hands and on the first opaque surface within the eyes. According to him, these dual patterns, in turn, assume an active role, reproducing themselves in the pineal gland.

\section{Criticism}

In postulating that we have direct face-to-face apprehension of patterns in the brain (in his explanation of the interaction of mind and body at the pineal gland), Descartes succeeded in escaping certain of the difficulties in which, on the usual interpretation of his theory, he was inextricably entangled. For though he still advocated a doctrine of representative perception, the correspondence to be established is no longer between objects and physical bodies, but between brainpatterns (ideas corporeal) and the distant bodies - mechanically generative of them, the kind of correspondence which can find more or less adequate analogies

${ }^{17}$ K. S. Norman, New Studies in the Philosophy of Descartes (London: Macmillan, 1966), 144.

(c) 2012 Akomolafe Akinola Mohammed http://www.kritike.org/journal/issue 11/mohammed june2012.pdf ISSN 1908-7330 
in the correlative movements of the lower and upper ends of a writer's pen or the behaviour of light in enabling an object to project an image of itself in a mirror.

However, when it was pointed out to Descartes that his solution to this mind-body problem was quite unsatisfactory, he became more and more vague about the matter, insisting that the fact of interaction is known to everybody; that we experience it all the time. But how mind and body are united, he admitted, is most difficult to explain. Reverting to common sense experience, he explained away the interaction as human daily experience in his correspondence to Arnauld on July 29,1648 , as follows:

That the mind, which is incorporeal, can set the body in motion - this is something which is shown to us not by any reasoning or comparison with other matters, but by the surest and plainest everyday experience. It is one of those self-evident things which we only make obscure when we try to explain them in terms of others. ${ }^{18}$

In my view, the pineal gland theory actually produced more problems than it solved, since one could ask whether this gland was physical, and if so, how it could be next to any part of the brain, etc. In a letter written late in his life to one of his admirers, Princess Elizabeth of the Palatinate, Descartes threw up his hands in despair, and told her (Princess Elizabeth) that the union of mind and body is best understood by not thinking about it, and that it is just one of those mysteries that has to be accepted without being comprehended. ${ }^{19}$

Many philosophers have viewed Cartesian dualism as a myth that must be destroyed. Thus, materialism, idealism, behaviourism, occasionalism, epiphenomenalism, the theory of pre-established harmony, double aspect theory, etc., are some of the theories that present themselves as better alternatives to Descartes' pineal gland theory. We shall now pick them one after the other.

Materialism. Materialism is best exemplified by behaviourism. Behaviourism is credited to Thomas Hobbes. Hobbes and Pierre Gassendi had maintained as materialists, that people are mainly physical entities having abilities that cannot be equated with other physical systems, indicating that people are merely a special kind of substance of physical nature. In his De Corpore, Hobbes attempts to explain all mental states in terms of physical states. His efforts received a massive favourable support, but the contemporary discussions on the theory, however, are associated with the work of J.B. Watson. According to D.M Armstrong,

\footnotetext{
${ }^{18}$ Descartes, The Meditations, 235.

${ }^{19}$ H. P. Richard \& S. Avrum eds., Philosophy Made Simple (London: W. H. Allen, 1956), 99.
}

(c) 2012 Akomolafe Akinola Mohammed http://www.kritike.org/journal/issue 11/mohammed june2012.pdf ISSN 1908-7330 
One account of mental process that is at once attractive to any philosopher sympathetic to a materialist view of man is behavourism. Formulated originally by a psychologist, J. B. Watson, it attracted widespread interest and considerable support from scientifically-oriented philosophers. ${ }^{20}$

The Central tenet of behaviourism is that mind is somehow reducible to behaviour. According to Armstrong, "The mind is not an inner arena, it is an outward act, which can be publicly observed."21 In his book, The Behaviour of Organisms, B. F Skinner explains 'behaviour' as the action of the organism upon the outside world. Gilbert Ryle in his book, The Concept of Mind, ridiculed the Cartesian view as the dogma of 'the ghost in the machine.' The mind, according to him, was not something behind the behaviour of the body; it was simply part of physical behaviour.

The position of philosophical behaviourists is that references to supposed inner states can always be eliminated, and in fact, it is a misconception to suppose that our ordinary talk about minds gives any credence to the Cartesian view of mind.

Essentially, when we ascribe a mental state to someone, what we are doing is not to infer the existence of some ghostly inner state on this basis of our observation of subject behaviour, but to characterize and assess just the observable behaviour of the subject. For instance, thought is not an inner process that lies behind, and brings about the words I speak and write: It is my speaking and writing.

Many criticisms have, however, been labelled against behaviourism. A. O. Lovejoy, in his attack on behaviourism, alleges that the cognitive claim of the behaviourists, expecially Watson's, involves them in contradiction. This contradiction is shown in: Awareness of objects distant in time and space which cannot be said to be the same with the movements of certain parts of the body. $\mathrm{He}$ gives 'sound' heard from a neighbourhood as an example. ${ }^{22}$ However, Watson maintains that such movements - mental and physical, are one and the same.

In his criticism of behaviourism, C. D. Broad says that no matter the way the behaviour of an external body answers to behaviouristic test for intelligence, it always remains a perfectly sensible question to ask: Has it really got a mind or is it merely an automation? For Broad, "a self-propelling quality or mind is different and can never share in the same terms - reference with physical behaviour. ${ }^{23}$

${ }^{20}$ D. M Armstrong, The Nature of Mind (London: The Harverster Press, 1981), 4.

${ }^{21}$ Ibid., 5.

22 P. Edward ed., The Encyclopedia of Philosophy, Vol 1\& 2 ( New York: Macmillan Company and the Free Press, 1967), 270.

${ }^{23}$ Ibid.

(C) 2012 Akomolafe Akinola Mohammed

http://www.kritike.org/journal/issue 11/mohammed june2012.pdf

ISSN 1908-7330 
In D. M. Armstrong's belief, behaviourism has failed in its efforts to produce a satisfactory account of the theory of mind. ${ }^{24}$

The fact is that we always hold thoughts to be distinct and never to be identified with behaviour. They are always invisible hands behind behaviour.

Richard Rorty also thinks that behaviourism has not succeeded in displaying the Cartesian account of the mind. On behaviourism, vis-à-vis its attempt to serve as a better option to Cartesian dualism, Rorty writes:

The behaviourists, at their epistemological best, thought that the only sort of entities directly present to consciousness were states of physical objects. The behaviourists prided themselves on escaping the notions of our Glassy Essence and the inner Eye but they remained true to Cartesian epistemology in retaining the notion of an Eye of the mind which got something first hand ${ }^{25}$

This first hand information arising from the eye of the mind then debunks one of the behaviourists' claims that all mental states are by-products of the physical states.

Epiphenomenalism. As a result of the problems of behaviourism, a modified form of the materialistic theory of mind and body has been developed. This is known as epiphenomenalism. This view admits that "our thoughts, feelings, etc., are not merely physical states in our brain. Instead, they are adjudged to be a by-product of the sequence of physical occurrences, something like the smoke given off by fire." 26

The position of the epiphenomenalists is that the significant events which occur in the world are only those of matter in motion. They further hold that but along with this, for reasons not yet known to us, each time there is a certain sort of physical situation in the brain, a thought occurs, which is caused by material events.

Though epiphenomenalism may mitigate the problems of materialism (behavourism), it fails to eliminate them altogether, for it does some deservice to our mental life. There is no doubt about it that we take our thoughts seriously, are concerned by them, reflect upon them, appear to initiate actions on the basis of them. If they are useless to us, there is no way they can play such a prominent role in our lives.

Idealism. This is diametrically opposed to materialism. It insists that the mental (mind) and the physical (body) are real, but that the mental is superior. If 1979), 105.

${ }^{24}$ Armstrong, The Nature of Mind, 7.

${ }^{25}$ R. Rorty, Philosophy and the Mirror of Nature (Princeton: Princeton University Press,

${ }^{26}$ H. P. Richard \& S. Avrum, Philosophy Made Simple, 101.

(C) 2012 Akomolafe Akinola Mohammed http://www.kritike.org/journal/issue 11/mohammed june2012.pdf ISSN 1908-7330 
one considers the position of some other idealists, who insist that only the mind is real, then like materialism, it becomes a reductionist theory. Idealism, in this light, when applied to the mind-body problem, flies in the face of our common-sense beliefs, and it is in apparent conflict with scientific evidence. Before reflecting on these matters at all, I seem to be convinced that there are physical events which influence our behaviour. Scientific data concerning the influence of say, drugs and surgery on our mental life suggest that an idealistic approach to the mind-body problem is difficult to accept, unless the arguments in its favour can far overweigh the initial conflicts with our ordinary beliefs.

Occasionalism. Among other views expressed by Descartes' critics on mind-body dualism is Occasionalism, which insists that, "No events cause other events at all, but God uses each event as it arises as the occasion for Him to cause the next event in what appears to us as a causal sequence." ${ }^{27}$

Occasionalism is associated especially with Nicholas Malebranche and Geulinex Arnauld. In Occasionalism, what happens, according to Malebranche, is that although mental events have nothing to do with physical ones, whenever anything happens in one realm, God makes something corresponding occur in the other. The events in one are not the causes of events in the other; they are only the occasions of God's actions. ${ }^{28}$

Thus, when I hear the ring of the telephone, this is not due to the occurrence of sound waves, which are part of the physical world, and have nothing to do with thoughts that I may have. Instead, when the events take place in the mechanism of the telephone, God produces a thought in me of ringing. Since one has nothing to do with the other, they might just as well have produced the taste of a pear in me, or the idea of the number. But through the inscrutable wisdom of God, He has decided to order my mental life and the series of physical events so that when a specific event occurs in one, He makes something else occur in the other.

No doubt, Malebranche's occasionalism avoids the problem of Descartes' speculations, and no experience can possibly disprove it. Descartes had insisted upon holding both to the complete separation of mind and body to their interaction. By eliminating the latter, Malebranche is able to hold to the former without encountering contradictions. Malebranche's occasionalism can be made to account for literally everything, since God is always employed as producing a certain effect in one realm when something else happens in the other.

Conversely, however, no matter how consistent Malebranche's theory may be, it remains extremely unconvincing in the light of our ordinary experience, which we naturally interpret in terms of some relation between mental and physical events. Again, Malebranche's conception of God as being constantly involved in

${ }^{27}$ G. H. R Parkinson ed., An Encyclopedia of Philosophy, Vol. 1 (London: Routledge, 1988), 338.

${ }^{28}$ Rorty, Philosophy and the Mirror of Nature, 102.

(C) 2012 Akomolafe Akinola Mohammed http://www.kritike.org/journal/issue 11/mohammed june2012.pdf ISSN 1908-7330 
producing all effects in this world, as engaged in producing sounds, tastes, smells, and motions in the physical world - is hardly in keeping with most 'acceptable' concepts of the Deity.

A variant of occasionalism is Leibniz's view that every 'monad' (a kind of atom, but spiritual in nature) has a built-in programme which unfolds automatically without being affected by any other monad, though there is a 'pre-established harmony,' whereby unfoldings fit together into a coherent universe.

For Occasionalism of whatever variant, the fact that mental and physical events occur in a coherent connection with each other is simply attributed to God. It is this feature that makes this view alien to contemporary opinion. This led a writer to hold the opinion that,

No doubt God could play this role, but to appeal to Him in this way as an explanatory hypothesis is surely a counsel of despair, one could explain anything by just saying, 'Well, God decided it should be so.' It also leaves untouched the problem of the unity of a person. ${ }^{29}$

Leibniz's theory, like Malebranche's, overcomes the difficulties in Cartesian metaphysics, by giving up any claim that there is a relationship between mind and body. Also, like Malebranche's, Leibniz's view, though it may not contain any inconsistencies, is incredible from the point of view of our ordinary, common experience.

Double-Aspect Theory. Lastly to be considered is Spinoza's efforts at solving the mind-body riddle. In Spinoza's opinion, the difficulty in the Cartesian theory came from its total separation of mind and body and the total separation of both from God. To overcome this, Spinoza did not wish to adopt the materialistic or idealistic solution of subordinating one of these realms to the other, but instead, insisted that they were both aspects of the same thing. This theory, sometimes called the dual-aspect or double-aspect theory, claims that "mind and body are both attributes of one and the same entity", which Spinoza named God, Substance or Nature.

If the mental and the physical worlds are both aspects of the same entity (i.e God, Substance or Nature), what is the relationship between one and the other? For Spinoza, "All the relations within the one great system are logical relations and to know the truth about the whole system would be to know the logical connections that hold between all its parts. ${ }^{30}$

Since logical connections are necessary connections, if one could come to know all the truths of the system and their interconnections, one would then see

\footnotetext{
${ }^{29}$ Parkinson, An Encyclopedia of Philosophy, Vol. 1, 389.

${ }^{30}$ D. Collinson, Fifty Major Philosophers: A Reference Guide (London: Routledge, 1987), 62.
} 
that the universe contains nothing that is contingent or that could be other than it is. In Spinoza's opinion, "In the nature of things, nothing contingent is admitted, but all things are determined by the necessity of divine nature to exist and act in a certain way. ${ }^{31}$

Spinoza is of the view that there is no influence between mind and body, but there is parallellism; so that "for everything that happens in one realm, a corresponding event occurs in the other." ${ }^{32}$

According to him, whatever happens, happens by necessity in accordance with the causal laws of nature, and is a modification of God. For him, we are part of the universal nature, and we follow her order. Just as God and the physical universe (the Natura Naturans and the Natura Naturata) are one and the same thing, seen and known under the attributes of thought and extension, spirit and matter; so are the mind and the body in man one and the same thing under the attributes of spirit and matter. Consequently, man's mental activities are just as subject to, and determined by, the causal laws of nature as his bodily activities. He thus queries the reality of the pineal gland theory of Descartes in resolving the mind-body issue. ${ }^{33}$

From the foregoing, it can be said, that though Spinoza's metaphysical solution to the mind-body dualism may not lead to the same kind of unbelievable views as that of Malebranche or Leibniz, or the inconsistencies involved in Descartes' view; however, it led to certain conclusions regarding the nature of God, which most of his contemporaries found completely unacceptable. Consequently, it was not until the time of the nineteenth century German metaphysicians, that Spinoza's views were treated seriously.

From all indications, Spinoza's doctrine of attributes allows him to avoid the unattractive alternatives of materialism, idealism and Cartesian dualism, and thus to affirm the autonomous, self-contained nature of thought without making mind into a distinct substance. According to him, two of the infinite attributes of the one substance, thought and extension are not separate entities, but "irreducible and distinct expressions of one and the same reality." ${ }^{34}$ Since the human mind and the human body are finite modifications of these attributes, the same conclusions can be applied to them. Thus, while the mind cannot by some mysterious power determine the body to act, nor the body causes the mind to think, an act of thought and its physical correlate in the realm of extension are intimately related as two strictly parallel expressions of the same state of affairs. One could express this in contemporary terms by saying that mind and body are related functionally rather than causally, with 'function' being taken in its mathematical sense ${ }^{35}$

\footnotetext{
${ }^{31}$ Ibid., 62.

${ }^{32}$ Rorty, Philosophy and the Mirror of Nature, 104.

${ }^{33}$ Vesey, Body and Mind, 61.

${ }^{34}$ H. E. Allison, Bebedict de Spinoza (Boston: Twayne Publishers, 1975), 88.

${ }^{35}$ Ibid., 88-89.
} 
Other critics of Descartes have argued that his Meditations contain logical inconsistencies. Here, according to them, are a few examples:

Firstly, Descartes' dreaming doubt is said to have been stated so loosely that a large number of commentators are struggling to determine exactly what the doubt is and whether it is valid. Also, Descartes' doubt concluded with his conjuring, the deceiving demon, which he used to 'deceive himself.' Again, the assumption that he is dreaming is contradicted at the end of Meditation I when Descartes likened his doubt to wakefulness itself. And one expects that the demon would lead the doubt in Meditation II, he is however, capriciously dropped and replaced by 'a god'

Moreover, Meditation II firmly asserts the certainty and truth of the socalled 'cogito argument,' and dramatises it as the Archimedean point whose unshakeability conquers the effort of 'a god' to deceive him. Yet, in Meditation III, despite a vigorous repetition of this drama, Descartes declares that nothing is certain until the existence of a honest God is established.

Furthermore, Descartes' position on the mind-body issue can be criticised on the logical positivist standpoint. To the logical positivists, the meaning of any proposition depends on its method of verification; and since the whole idea of mind is unverifiable empirically, logical positivists see it as being meaningless, since it can only be metaphysical.

Descartes has also been criticized on his notion of 'thought.' For instance, John Cottingham, in his article, "Descartes on Thought", writes:

The gloss Descartes offers on 'a thing which thinks' (res cogitans) is quite extraordinary. Doubting and understanding are evidently kinds of thinking. But it is far from obvious that affirming, denying and willing are to be classified in this way. And as for 'feeling' (sensitive), this is, in any normal sense, something entirely different from thinking. ${ }^{36}$

Descartes has also been accused of going in circle. In order to prove that his reason is reliable, he goes on to prove the existence of an absolutely honest God, who cannot deceive him; but he uses this very existence of God, which he has not yet proved to be reliable to prove the reliability of his reason. He eventually uses this reasoning to come about his 'cogito ergo sum,' which is the origin of his mind, the thinking substance. Here, some fundamental elements of Descartes' arguments are ambiguous. Peter J. Markie has this to say on Descartes' line of reasoning:

${ }^{36}$ J. Cottingham, "Descartes on Thought," in The Philosphical Quarterly, 28 (July 1978), 208.

(c) 2012 Akomolafe Akinola Mohammed http://www.kritike.org/journal/issue 11/mohammed june2012.pdf ISSN 1908-7330 
As he begins the Third Meditation, Descartes introduces the notion of clear and distinct perception and goes on to argue that God is not a deceiver and that all his clear and distinct perceptions are true. Some important aspects of his line of reasoning are unclear. ${ }^{37}$

Very importantly also, as scientific studies beam their searchlight upon the mysteries of the human mind, Descartes' dualism has come under intense criticism. Strengthened by the fact of great successes of over three centuries of purely scientific researches, scientists now reject Descartes' dualism. In this connection, most scientists believe that our mental and spiritual lives are wholly dependent upon the workings of our brains. That means when the brain dies, the stream of our being must come to an end. ${ }^{38}$

However, in spite of the strong opposition to Cartesian dualism, and indeed, to the interaction between the mind and the body being championed by science, there are many reasons to believe that the methods of science are insufficient to either prove or disprove the idea that brains produce consciousness. Little wonder, then, that Sam Harris avers that, "Nothing about a brain, when surveyed as a physical system, declares it to be a bearer of that peculiar, interior dimension that each of us experiences as consciousness." ${ }^{39}$ This paper aggress with the view that whether the perspective of experience is through the study of priming effects and visual masking, change blindness ${ }^{40}$; visual extinction and visuospatial neglect ${ }^{41}$; binocular rivalry and other bistable precepts ${ }^{42}$; or blind sight ${ }^{43}$, the fact remains that the mark of consciousness perception is always the same.

Furthermore, it has been plausibly argued that, If the term 'I' refers to anything at all, it does not refer simply to the body; after all, most of us feel individuated as a self within the body. ${ }^{44}$ This point can also be buttressed by the fact that one can speak of his body more or less as he speaks of his car, his house, his pen or his book; for the simple reason that every act of perception or cognition suggests the implied logic that the knower is something different from the thing known.

37 P. J. Markie, "Fred Feldman and Cartesian Circle," in Philosphical Studies: An International Journal of Philosophy in the Analytic Tradition, 31 (1977), 427.

${ }^{38}$ S. Harris, The End of Faith (London: Simon \& Schuster Uk Ltd., 2006), 208.

${ }^{39}$ Ibid., 208.

${ }^{40}$ D. J. Simons et al., "Evidence for Preserved Represenatations in Change Blindness," in Consciousness and Cognition, 11 (2002), 79.

${ }^{41}$ G. Rees, et al., "Neural Correlates of Consciousness in Humans," in Nature Reviews Neuroscience, 3 (2002), 261-70 (2002), 19

${ }^{42}$ R. Balke \& N. K. Logothetis, "Visual Competition," in Nature Reviews Neuroiscience, 3 70.

${ }^{43}$ L. Weiskrantz, "Prime-Sight and Blind sight," in Consciousness and Cognition, 11 (2002),

${ }^{44}$ Harris, The End of Faith, 211.

(c) 2012 Akomolafe Akinola Mohammed http://www.kritike.org/journal/issue_11/mohammed june2012.pdf ISSN 1908-7330 


\section{Conclusion}

From the foregoing analysis, there is no doubt that Descartes has succeeded in bifurcating human personality into mind and body. However, his attempt at resolving the riddle of interaction between them is unsuccessful. None of the theories that have been put forward to serve as alternative explanations to Descartes' account has been able to solve the problem. Even scientific studies into the problem have been able to resolve the issue either.

In conclusion, hence, even though there have been many arguments in support and against the mind-body problem, at best, this study can only see the interaction of the two distinct substances as probable. The fact is that if the reductionist position of scientists is accepted, that means only the physical, corporeal things such as the brain, body, etc. exist. It also means that the so-called thinking activities, as observed by Descartes are solely carried out by the brain. As the scientists would hold, if the brain dies, the entire thought-system stops working; as a result, the brain therefore is the self.

However, if the position of the idealists is considered, one discovers that even if the thought-system is ascribed to the brain, what about the reflection on the things thought of? Or if the brain is considered to be the organ responsible for consciousness, does it mean that the man in coma is not a person? No doubt, scientists are yet to show how the brain can carry out the process of reflection. In this connection, when one considers the experience of dreaming, clairvoyance or telepathy, science needs a lot of justification to do in order to show that such an activity is performed by the brain, because nothing about a brain can be attributed to such an interior dimension each one of us experiences in each of the situations mentioned above as consciousness.

In the final analysis, even though Descartes failed to explain away his pineal gland theory vis-à-vis the interaction of mind and body; his theory, however, generated no little controversy. This went a long way in stirring the tide of scholarship, both in his life-time, and thereafter, more so, in the last two decades. Little wonder then that a scholar of Analytic School, Hiram Caton, has this to say on Descartes and his dualism:

It used to be said that Cartesian mind was the relic of religious nonsense - a ghost in a machine, that the Cogito argument was a short compendium of logical howlers; that his doubt offended common sense to the point of being unBritish; that the proof of God's existence was contemptibly circular, and so on. But the brash goblinry toward Descartes ... faded as more and more metaphysics popped up in the 


\section{A. MOHAMMED 111}

empiricist sandbox ... The rehabilitation of history of philosophy, once marked as the veriest kingdom of darkness, is a nice symptom of the change. For over a decade now it has been a growth area, and Descartes' share of the market is substantial. ${ }^{45}$

Without doubt, his influence will continue to grow among great philosophers of our time and the philosophers yet to arrive on the scene.

Department of Philosophy, Lagos State University, Nigeria

\section{References}

Allison, H. E., Bebedict de Spinoza (Boston: Twayne Publishers, 1975).

Anthony, K. ed., Descartes' Philosophical Letters (London: Oxford University Press, 1970).

Armstrong, D. M, The Nature of Mind (London: The Harverster Press, 1981).

Balke, R. \& N. K. Logothetis, "Visual Competition," in Nature Reviews Neuroiscience, 3 (2002).

Collinson, D., Fifty Major Philosophers: A Reference Guide (London: Routledge, 1987).

Cottingham, J., "Descartes on Thought," in The Philosphical Quarterly, 28 (July 1978).

Descartes, R., The Meditations, Trans by John Veitch, (Illinios: The Open Court Publishing Company, 1966).

Edward, P. ed., The Encyclopedia of Philosophy, Vol 1\& 2 (New York: Macmillan Company and the Free Press, 1967).

Harris, S., The End of Faith (London: Simon \& Schuster Uk Ltd., 2006).

Hiram, C., "Analytic History of Philosophy: The Case of Descartes," in The Philosophical Forum, A Quarterly, XII (Summer 1981).

Markie, P. J., "Fred Feldman and Cartesian Circle," in Philosphical Studies: An International Journal of Philosophy in the Analytic Tradition, 31 (1977).

Norman, K. S., New Studies in the Philosophy of Descartes (London: Macmillan, 1966).

Parkinson, G. H. R ed., An Encyclopedia of Philosophy, Vol. 1 (London: Routledge, 1988).

${ }^{45}$ C. Hiram, "Analytic History of Philosophy: The Case of Descartes," in The Philosophical Forum, A Quarterly, XII ( Summer 1981), 273.

(C) 2012 Akomolafe Akinola Mohammed http://www.kritike.org/journal/issue_11/mohammed june2012.pdf ISSN 1908-7330 
Rees, G., et al., "Neural Correlates of Consciousness in Humans," in Nature Reviews Neuroscience, 3 (2002), 261-70

Richard, H. P. \& S. Avrum eds., Philosophy Made Simple (London: W. H. Allen, 1956).

Rorty, R., Philosophy and the Mirror of Nature (Princeton: Princeton University Press, 1979).

Simons, D. J. et al., "Evidence for Preserved Represenatations in Change Blindness," in Consciousness and Cognition, 11 (2002).

Vesey, G. N.A. ed., Body and Mind, (London: George Allen \& Unwin Ltd., 1964).

Weiskrantz, L., "Prime-Sight and Blind sight," in Consciousness and Cognition, 11 (2002). 